\title{
Blog assisted learning: Experiences in learning Business English vocabularies
}

Ching, Gregory S. \

Lunghwa University of Science and Technology, Taiwan, ROC (gregory_ching@yahoo.com)

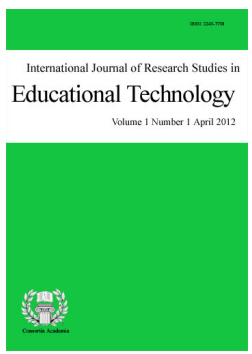

ISSN: $2243-7738$ Online ISSN: 2243-7746

OPEN ACCESS

\section{Abstract}

Information Technology (IT) is currently seen and felt in almost every aspect of our daily lives. In addition, the shift of the traditional literacies to the current notion of multiliteracies is caused by the rapid evolution and integration of IT in an age of increased cultural diversity and global connectedness. Such changes did not only change the way students' learn, but it also changed the students' perception of text. Furthermore, within the last decades, the rise in popularity of the concept of English for Specific Purpose (ESP) language learning has also encouraged dramatic curricular changes in Taiwan. Recently, students are much influence by the prevalent use of computer mediated communication (CMC) in terms of their English language learning. Students tend to use unorthodox text in their day to day CMC, hence, affected their formal language learning. In light of these situations, this study shall attempt to analyze the influence of maintaining and interacting with a blog posting while learning various Business topics. Participants are a group of volunteer students from the Applied Foreign Languages (AFL) department of a technical vocational university in Taiwan. Students gathered every two weeks for three months to meet and discuss pre-selected topics regarding Business English. Each student is then required to give their reactions and insights regarding the meeting topics through the use of blog entries. Students also take turns in taking the role of topic leaders, which are tasked with giving corrections and reactions with regards to the blog entries. Themes where then generated and analyzed from the students interviews, reactions, and insights. Results show that the peer cooperative learning opportunity combined with blog discussions have positively contributed to the enhancement of the students' Business English vocabulary learning.

Keywords: English for Specific Purpose; blog discussions; cooperative learning; Business English; computer mediated communication; vocabulary enrichment 


\section{Blog assisted learning: Experiences in learning Business English vocabularies}

\section{Introduction}

The ubiquitous nature of the world-wide-web has indeed drastically changed the way we conduct our daily lives. Most people, especially the students are so interconnected to each other by means of various type of technology (Chambers, 2004). As students embraces the age of multiliteracies; a term coined by the New London Group (1996), which describe the impact of information technologies on the ways people use and interacts with information, increasing concerns with regards to how student learns was also observed. Embracing this change, educators have started to adapt these concepts in order to maximize students' learning. Beyond this spectrum, an increased in development of English for Specific Purpose (ESP) courses was also observed recently in Taiwan. Currently, English is being regarded as the de-facto language in the areas of banking, commerce, and trade. Hence, much emphasis is placed on ESP courses such as "Business English".

In the classroom setting, the emphasis on the need for higher education institutions to help develop team building skills in students, have also brought much attention to school administrators (Dimmock, 2000; Harris \& Lambert, 2003). Within the current age of globalization and internationalization, collaboration and cooperation among students of diverse cultural background are also strongly encouraged (Barnett, Basom, Yerkes, \& Norris, 2000). In Taiwan, the development of both leadership and communication skills in students are seen as an important core competencies (Wu, Chen, \& Lin, 2004; Yen, Chen, Leea, \& Koh, 2003), hence inclusion of such developmental program in the curricula should be encouraged (J.-F. Hsu \& Gregory, 1995).

In light of such issues, students of today shall need to both develop a good Business English skills and leadership capacity before graduation. These are seen as vital component in the students' future careers. More so, with the prevalent of computer mediated communication (CMC) in the society, the use of the English language will become so common and shall take the lead in making more effective social connections. Therefore, the help of a creative, cooperative, and technologically assisted activity to master Business English skills are some important methodology that should be explore. The current study shall depict the experiences in using a blog assisted strategy used in learning Business English.

\subsection{Rise of ESP in Taiwan}

In Taiwan, within the paradigm of multiliteracies, the rise in popularity of the concept of ESP language learning in English as a Foreign Language (EFL) countries has also encouraged dramatic curricular changes. Currently, English is being regarded as the de-facto language in the areas of banking, commerce, trade, research, technology, and tourism (Tsai, 1998). As Taiwan engages more centrally as a player in the global economic stage (Mok, 2005; Zaharia \& Gilbert, 2005), the trend of using English as a medium of business transaction has become an increasingly important element for the education of Taiwan students. In its role as a global language, English has already become one of the most important academic and professional tools (Schutz, 2006). Therefore, it is quite important to find effective ways in combining current educational technology in teaching Business English to Taiwanese students.

ESP has been around since the early 1960s (Strevens, 1977), It actually originated from the massive expansion of scientific, technical, and economic activities on an global scale, which resulted in the increased demands on English communication (Dudley-Evans \& St John, 1998). In addition, with the usage of English varying from context to context, hence English language practitioners have been pressured to adapt to the needs of the learners within their specific environment. It is noted that advocate of ESP practiced an approach to language teaching in which all decisions as to content and method are based on the learner's reasons for learning (Law, 1996). 
In the past decades, English was once a required course for college students in Taiwan, which emphasized the reading of literature (Chia, Johnson, Chia, \& Olive, 1998). However, in 1993 the Taiwanese Ministry of Education (MOE) abolished the mandatory English reading requirements in higher education institutions (HEIs), due to the growing concerns that both the English language teaching and curricula had been ignoring the students' needs (Chia et al., 1998; Law, 1996; Liaw, 2009). This phenomenon opened up the opportunities for Taiwanese HEIs to freely design their own English language learning courses based on a content focus or a designated-skill focus. In spite of this, such courses were still not developed on the basis of an analysis of the English language needs of college students (Chia et al., 1998). Therefore, there is a serious need to develop an ESP course, which covers the two absolute components Strevens (1988) mentioned; needs assessment and discourse analysis.

Recently, HEIs in Taiwan have been encouraging English taught course programs, offering more ESP courses, requiring students to pass the Test of English for International Communication (TOEIC) prior to graduation (Chien, Lee, \& Kao, 2008). These actually brought forth by the need for HEIs to become internationally competitive amidst the age of globalization and internationalization (Butler, 2005; Chang, 2005), which created changes in the goal of teaching English (Borsheim, Merritt, \& Reed, 2008). The trend of studying English as a medium of communication in the business arena has become an increasingly important element in the education of Taiwanese students. More so, the recent importance placed on ESP in Taiwan's language and linguistic academic domain is indicated by the establishment of Taiwan ESP Association in 2008 (Taiwan ESP Association, 2010). Therefore, ESP in Taiwan, more specifically learning "Business English" has become a strong necessity for the future graduates' career.

\subsection{Multiliteracies and Learning}

Many mentioned that the shift of the traditional literacies to the current notion of multiliteracies is caused by the rapid evolution and integration of information technology (IT) in an age of increased cultural diversity and global connectedness (Borsheim et al., 2008; Richardson, 2006). In general, the concept of multiliteracies originated with the New London Group (1996), which refers to two issues regarding the evolution of language today. The first is the variability of meaning making in the different cultural, social or domain-specific contexts whereas the second is the impact of information technologies on the ways people use and interacts with texts. Overall, these issues inevitably affect how people communicate and more importantly influence how education is achieved (Chandler-Olcott \& Mahar, 2003; Cook-Gumperz, 1986; Cope \& Kalantzis, 2000).

In the English as a foreign language (EFL) setting, traditional definitions of literacy have focused on reading and writing, however, the definition of literacy today is more complex. The process of becoming literate today is not limited to learning how to use language effectively, but is the summation of the multimodal linguistic and cognitive functioning of the individual in society (Cope \& Kalantzis, 2000). Anstey and Bull (2006) stated that a multiliterate person is someone who is flexible and strategic, and can understand and use literacy and literate practices with a range of texts and technologies. Ultimately, multiliterate individuals possess a range of skills that enable them to participate fully in all aspects of modern society, from workforce to family and to academic community.

In the educational setting, practitioners who advocate a multiliteracies pedagogy offer students enough opportunities to access, evaluate, search, sort, gather, and read information from diverse multimedia and multimodal sources (Borsheim et al., 2008). Hence, students who learn in multiliterate settings, use collaborative learning in both real and virtual spaces, produce and publish multimedia and multimodal texts for a variety of audiences and purposes (Anstey \& Bull, 2006). In essence, to be considered multiliterate, students must acquire a battery of skills that will enable them to take advantage of the multimodal forms of communication made possible by the advancement of IT. 


\subsection{IT and Cooperative Learning}

Cooperation is mainly defined as the association of persons for a common benefit (Cooperation, 2010), or simply put is the process of working together to accomplish shared goals. Within cooperative activities individuals seek outcomes that are beneficial to themselves and beneficial to all other group members. Cooperative learning is a relationship in a group of students that requires positive interdependence (a sense of sink or swim together), individual accountability (each of us has to contribute and learn), interpersonal skills (communication, trust, leadership, decision making, and conflict resolution), face-to-face interaction, and processing (reflecting on how well the team is functioning and how to function even better) (Johnson, 1993; Johnson \& Johnson, 1989; Johnson, Johnson, \& Holubec, 1993). Hence, cooperative learning is the instructional use of small groups so that students work together to maximize their own and each other's learning (Johnson, 1993).

CMC is basically defined as any form of human interaction across two or more networked computers (Thurlow, Lengel, \& Tomic, 2004). While, net-lingo (or net-lingua) and emoticons are acronyms, abbreviations used in writing that have typically been pronounced as a word (Thurlow, 2001). Recently, the prevalent use of CMC has already influenced the students' English language learning (Biesenbach-Lucas, 2003; O'Rourke, 2008). Some even claimed that the decreased in students' performance in English language performance especially in their writing competence are caused by long term used of net-lingo or emoticons in CMC (Vogel \& Janssen, 2009; Walther \& D'Addario, 2001). This notion is justifiable, as it is possible that much exposure to informal language usage can lead to unconscious usage in formal writing tasks.

Many studies have been done regarding the combination of ICT and cooperative learning pedagogy. Researchers mentioned that the knowledge-building processes occurring in asynchronous discussion (such as blogs and wikis), do indeed possess much potential in enhancing the learners' competence (Schrire, 2006). Similarly, Hammond (2000) mentioned that online discussions (including the exchange of personal information) and maintaining blog postings (such as peer review of essays and reflection logs) are both beneficiary to the learners' knowledge gain. Some studies have mentioned that cooperative learning in extra-curricular activities helps in both enhancing the students language proficiencies and leadership capabilities (T. C. Hsu, 2011). In essence, CMC if used properly and designed together with cooperative learning efforts, should provide students with a non-threatening and accessible way to enhance their English language proficiencies.

\section{Research methodology}

This research is designed as a case study, wherein the primary objective is to investigate a contemporary phenomenon within its real-life context; when the boundaries between phenomenon and context are not clearly evident; and in which multiple sources of evidence are used (Yin, 1984, p. 23). Furthermore, Merriam (1998) views a case as an individual, a program, a class or students, a school, or a community. She fashions the distinctiveness of case studies as particularistic because of the focus on one social unit; descriptive because they result in a rich thick portrait; and heuristic because case studies sharpen readers' understanding while leading to a new meanings.

This study also employed the descriptive research paradigm; a qualitative research that is concerned with how something that exists is related to some preceding event that has influenced or affected a present condition or event. Descriptive research, according to Best (1970) is concerned with conditions or relationships that exist, practices that prevail, beliefs, points of views, or attributes that are held, processes that are ongoing, effects that are being felt; or developing trends. Kvale (1996) defined qualitative research interviews as an attempt to understand the world from the subjects' point of view, to unfold the meaning of peoples' experiences, and to uncover their lived world prior to scientific explanations. Likewise, focus group interviews are among one of the most widely used qualitative research tools in social sciences studies. A probable benefit of this approach is that interviewees may feel greater confidence in a group setting, which may encourage them to offer comments and 
Blog assisted learning: Experiences in learning Business English vocabularies

discuss matters they would not in a one-on-one interview (Axinn \& Pearce, 2006).

\subsection{Research participants and research process}

Participants are a total of 10 volunteer students from the Applied Foreign Languages (AFL) department of a technical vocational university in Taiwan. Students were gathered once a week for three months to meet and discuss pre-selected topics regarding Business English. Each student is then required to give their reactions and insights regarding the meeting topics through the use of blog entries. Students also take turns in taking the role of topic leaders, which are tasked with the providing giving of corrections and reactions with regards to the blog entries.

In the first month, the participants discussed the topic that they wanted to do and made a decision. Afterwards, the participants undertake literature reviews on related researched regarding the use of net-lingo and computer mediated communication. Since we often see that people chat or write using the net-lingo, the participants believed that such topic is of significant importance. At first, the researchers looked up the literature review to know that if somebody has done this research before and some try to learn some common net-lingo. Starting the second month, the participants started to read articles on the blogs and made comments once a week. Each person needed to read the article and made a comment on the blog. When the participants write the comment, they may choose to use the net-lingo.

In the formal writing, participants are not allowed to used informal words, so one of the people in the group had to correct the mistakes made by the member participants. If the participants used the informal words, the person would correct the comments. In total the group had seen seven topics and made comments. After this, the participants wrote their personal opinions regarding the research process and the topic contents, these data were then analyze to form the advantages and disadvantages.

\subsection{Research instrument and data analyses}

The instrument used in this study is the various blog postings posted by the participants' adviser and comments done by the students. Topic ranges from several timely issues regarding career management and self-help issues. General and specific business related vocabularies are also noted and explained at the end of each blog posting. For the data analyses procedures, data gathered are the qualitative reflection write-ups by the participants. These data were analyzed using the Miles and Huberman (1994) method for generating meaning. The resulting themes were listed and together formed the implications of a cooperative co-curricular activity that enabled the students' Business English vocabularies development.

\section{Results and Discussions}

The primary objective of this study is to examine the implications of a cooperative co-curricular activity with regards to the students' Business English vocabularies development. Results are as follows:

After the three months participation in the blog assisted cooperative co-curricular activity, student participants are asked to write a reflective log indicating their comments and perceived advantages and disadvantages regarding such activity. Furthermore, these shall be concluded with a summarized of the various re-emerging themes using the Miles and Huberman (1994) method for generating meaning. For the emerging themes of the various reflective logs, a total of four major themes were listed. Table 1 shows the different themes together with the different items in each theme.

Within the emerging themes, four major issues were found to be common with most of the participants. Namely: English language improvement, the advantages of cooperative learning, and the advantages of using technology and net-lingo, and the gaining additional knowledge previously unknown. Within the English language improvement, student participants perceived that they show significant improvement not only with 
Ching, G. S.

their Business English vocabulary, but also on their General English language competencies. In addition, students also mentioned that both their reading and writing skills improved together with their grammar.

Each time we talked about the topic, I think I learn additional information. Not only about the information within the topics. My knowledge of Business English terms also increased. Regarding the reactions using blog writings, I believed my writing skills improved. I can now write more clearly. (Reflection - 2)

I felt that I learned a lot of new vocabularies. Learning with the use of technology is fun and exciting. My English really improved. (Reflection - 7)

Besides the English language competency gains, the students also mentioned that they learn a lot of additional knowledge with regards to career development and even basic practical knowledge that can help them improve in all aspects of their career. In addition, the cooperative strategies involved in the blog posting have also triggered the students' sense of responsibility. Students claimed that they are quite comfortable with this kind of mentoring style. They learn from one another and tend to improved on their weakness. More so, the use of technology in day to day computer mediated communication has also given many insights on the right usage and proper venue for such applications.

Working together is very fun. I learn a lot by taking the role of the leader. (Reflection -4)

\section{Table 1}

Reflective logs themes

Items

1. English language improvement

- Learn many new Business vocabularies

- Learn writing skills

- Have a more clear concept of grammar

- Make use of reading skills

- Find out the mistakes which people often make, then try to avoid it

- Make progress in English day by day

2. Cooperative learning

- Learning corporately is essential

- Fun to belong to a research group

- Learn advantage and improved our drawbacks from group members

3. Use of technology

- Learn how to use net-lingo and comment on articles

- Find out that net-lingo is convenience to use

- Know much information about Internet

4. Gain additional knowledge

- Gain a great deal of knowledge from reading the articles

- Realize how to choose a right career

- Gain the knowledge that we don't know before 


\section{Conclusion}

Recently, much concern regarding the students English language proficiency is observed. With the increased emphasis placed on ESP Business English courses, such creative and cooperative CMC co-curricular activity is deem important to enhance the students' language competence. In essence, this study was able to provide various important implications to the different stakeholders in the academic community.

This case study attempts to analyze the influence of maintaining a blog posting with regards to the students' Business English language learning. Participants are a group of volunteer students from the Applied Foreign Languages (AFL) department of a technical vocational university in Taiwan. Students were gathered once a week for three months to meet and discuss pre-selected topics regarding Business English. Each student is then required to give their reactions and insights regarding the meeting topics through the use of blog entries. Students also take turns in taking the role of topic leaders, which are tasked with the providing giving of corrections and reactions with regards to the blog entries. Themes where then generated and analyzed from the students reactions and insights.

Results indicate that besides the Business English vocabulary competencies gains, the students also mentioned that they learn a lot of additional knowledge with regards to career development and even basic practical knowledge that can help them improve in all aspects of their career. In addition, the cooperative strategies involved in the blog posting have also triggered the students' sense of responsibility. Students claimed that they are quite comfortable with this kind of mentoring style. They learn from one another and tend to improved on their weakness.

NOTE: Early versions of this paper were presented in the 2011 9th Biennial Conference of Asian Association of Social Psychology and in the 2012 Hawaii International Conference on Education.

Acknowledgement: The study was supported by funding from the National Science Council, Taiwan (Project No. NSC 99-2632-S-262-001-MY3). I am grateful to the anonymous reviewers for the valuable comments and suggestions.

\section{References:}

Anstey, M., \& Bull, G. (2006). Teaching and learning multiliteracies: Changing times, changing literacies. Newark, DE: International Reading Association.

Axinn, W. G., \& Pearce, L. D. (2006). Mixed method data collection strategies. New York: Cambridge University Press. <http://dx.doi.org/10.1017/CBO9780511617898>

Barnett, B. G., Basom, M. R., Yerkes, D. M., \& Norris, C. J. (2000). Cohorts in educational leadership programs: Benefits, difficulties, and the potential for developing school leaders. Educational Administration Quarterly, 36(2), 255-282. <http://dx.doi.org/10.1177/0013161X00362005>

Best, J. W. (1970). Research in education. Englewood Cliffs, NJ: Prentice Hall.

Biesenbach-Lucas, S. (2003). Asynchronous discussion groups in teacher training classes: Perceptions of native and non-native students. Journal of Asynchronous Learning Network, 7(3), 24-46.

Borsheim, C., Merritt, K., \& Reed, D. (2008). Beyond technology for technology's sake: Advancing multiliteracies in the twenty-first century. Clearing House: A Journal of Educational Strategies, Issues and Ideas, 82(2), 87-90.

Butler, Y. G. (2005). Comparative perspectives towards communicative activities among elementary school teachers in South Korea, Japan, and Taiwan. Language Teaching Research, 9(4), 423-446. $<$ http://dx.doi.org/10.1191/13621688051r1760a>

Chambers, C. (2004). Technological advancement, learning, and the adoption of new technology. European 
Journal of Operational Research, 152(1), 226-247.

$<$ http://dx.doi.org/10.1016/S0377-2217(02)00651-3>

Chandler-Olcott, K., \& Mahar, D. (2003). "Tech-savviness" meets multiliteracies: Exploring adolescent girls' technology-mediated literacy practices. Reading Research Quarterly, 38(3), 356-385. $<$ http://dx.doi.org/10.1598/RRQ.38.3.3>

Chang, Q. S. (2005). Internationalization of higher education from the perspective of globalization. Retrieved October 25, 2008, from http://english.education.edu.tw/ct.asp?xItem=7166\&ctNode=512\&mp=12

Chia, H. U., Johnson, R., Chia, H. L., \& Olive, F. (1998). English for college students in Taiwan: A study of perceptions of English needs in a medical context. English for Specific Purposes, 18(2), 107-119. $<$ http://dx.doi.org/10.1016/S0889-4906(97)00052-5>

Chien, C. N., Lee, W., \& Kao, L. H. (2008). Collaborative teaching in an ESP program. Asian EFL Journal, 10(4), 114-133.

Cook-Gumperz, J. (1986). Literacy and schooling: An unchanging equation? In J. Cook-Gumperz (Ed.), The social construction of literacy (pp. 16-44). Cambridge, UK: Cambridge University Press.

Cooperation. (2010). In Merriam-Webster Online Dictionary. Retrieved January 13, 2010, from http://www.merriam-webster.com/dictionary/Cooperation

Cope, B., \& Kalantzis, M. (2000). Multiliteracies: Literacy learning and the design of social futures. New York: Routledge.

Dimmock, C. (2000). Designing the learning-centred school - A cross-cultural perspective Abingdon, Oxon: RoutledgeFalmer.

Dudley-Evans, T., \& St John, M. (1998). Developments in ESP: A multi-disciplinary approach. Cambridge: Cambridge University Press.

Hammond, M. (2000). Communication within on-line forums: The opportunities, the constraints and the value of a communicative approach. Computers and Education, 35(4), 251-262. $<$ http://dx.doi.org/10.1016/S0360-1315(00)00037-3>

Harris, A., \& Lambert, L. (2003). Building leadership capacity for school. Berkshire, England: Open University Press.

Hsu, J.-F., \& Gregory, S. R. (1995). Developing future hotel managers in Taiwan: From an industry viewpoint. International Journal of Hospitality Management, 14(3-4), 261-269. <http://dx.doi.org/10.1016/0278-4319(95)00029-1>

Hsu, T. C. (2011). Enhancing college students' global awareness through campus Toastmasters clubs. International Journal of Research Studies in Education. 1(1), 21-34. $<$ http://dx.doi.org/10.5861/ijrse.2012.v1i1.1>

Johnson, D. W. (1993). Reaching out: Interpersonal effectiveness and self-actualization (6th ed.). Needham Heights, MA: Allyn \& Bacon.

Johnson, D. W., \& Johnson, R. T. (1989). Cooperation and competition: Theory and research. Edina, MN: Interaction Book Company.

Johnson, D. W., Johnson, R. T., \& Holubec, E. J. (1993). Cooperation in the classroom (6th ed.). Edina, MN: Interaction Book Company.

Kvale, S. (1996). Inter views: An introduction to qualitative research interviewing. Thousand Oaks, CA: Sage.

Law, W. W. (1996). The taiwanisation, democratisation and internationalisation of higher education in Taiwan. Asia Pacific Journal of Education, 16(1), 56-73. <http://dx.doi.org/10.1080/02188799608542611>

Liaw, M. L. (2009). Panel discussion: Contexts in ESP. Paper presented at the 2009 International Symposium on ESP \& Its Application in Nursing \& Medical English Education, Fooyin University, Kaohsiung, Taiwan.

Merriam, S. B. (1998). Qualitative research and case study applications in education. San Francisco: Jossey Bass.

Miles, M., \& Huberman, M. (1994). Qualitative data analysis (2nd ed.). Beverly Hills, CA: Sage.

Mok, K. H. (2005). Fostering entrepreneurship: Changing role of government and higher education governance in Hong Kong. Research Policy, 34, 537-554. <http://dx.doi.org/10.1016/j.respol.2005.03.003>

New London Group. (1996). A pedagogy of multiliteracies: Designing social futures. Harvard Educational Review, 66(1), 60-92.

O'Rourke, B. (2008). The other C in CMC: What alternative data sources can tell us about text-based synchronous computer mediated communication and language learning. Computer Assisted Language Learning, 21(3), 227-251. <http://dx.doi.org/10.1080/09588220802090253>

Richardson, W. (2006). Blogs, wikis and podcasts: And other powerful tools for classrooms. Thousand Oaks, CA: Corwin Press.

Schrire, S. (2006). Knowledge building in asynchronous discussion groups: Going beyond quantitative analysis. 
Blog assisted learning: Experiences in learning Business English vocabularies

Computers and Education, 46(1), 49-70. <http://dx.doi.org/10.1016/j.compedu.2005.04.006>

Schutz, R. (2006). English made in Brazil [Electronic Version]. Retrieved March 22, 2006, from http://frankherles.wordpress.com/2007/11/27/the-history-of-the-english-language/

Strevens, P. (1977). Special purpose language learning: A perspective. Language Teaching and Linguistics Abstracts, 10, 145-163.

Strevens, P. (1988). ESP after twenty years: A re-appraisal. In M. Tickoo (Ed.), ESP: State of the Art (pp. 1-13). Singapore: SEAMEO Regional Centre.

Taiwan ESP Association. (2010). Taiwan ESP association introduction. Retrieved January 30, 2010, from http://www.tespa.org.tw/about-eng.html\#m1

Thurlow, C. (2001). Language and the Internet. In R. Mesthrie \& R. Asher (Eds.), The concise encyclopedia of sociolinguistics (pp. 287-289). London: Pergamon.

Thurlow, C., Lengel, L., \& Tomic, A. (2004). Computer mediated communication: Social interaction and the internet. London: Sage.

Tsai, S. (1998). The effects of cooperative learning on teaching English as a foreign language to senior high school students. Unpublished Masteral thesis, National Kaohsiung Normal University, Kaohsiung, Taiwan.

Vogel, C., \& Janssen, J. F. (2009). Emoticonsciousness, Lecture Notes in Computer Science (including subseries Lecture Notes in Artificial Intelligence and Lecture Notes in Bioinformatics) (Vol. 5398 LNAI, pp. 271-287).

Walther, J. B., \& D'Addario, K. P. (2001). The impacts of emoticons on message interpretation in computer-mediated communication. Social Science Computer Review, 19(3), 324-347. <http://dx.doi.org/10.1177/089443930101900307>

Wu, J.-H., Chen, Y.-C., \& Lin, H.-H. (2004). Developing a set of management needs for IS managers: A study of necessary managerial activities and skills. Information \& Management, 41(4), 413-429. $<$ http://dx.doi.org/10.1016/S0378-7206(03)00081-8>

Yen, D. C., Chen, H.-G., Leea, S., \& Koh, S. (2003). Differences in perception of IS knowledge and skills between academia and industry: Findings from Taiwan. International Journal of Information Management, 23(6), 507-522. <http://dx.doi.org/10.1016/j.ijinfomgt.2003.09.011>

Yin, R. K. (1984). Case study research: Design and methods. Newbury Park, CA: Sage.

Zaharia, E. S., \& Gilbert, E. (2005). The entrepreneurial university in the knowledge society. Higher Education in Europe, 31(1), 31-40. <http://dx.doi.org/10.1080/03797720500088038> 
Ching, G. S. 